\title{
FALL RISK AND RELATED FACTORS IN KNEE OSTEOARTHRITIS
}

Turkish Journal of Geriatrics

DOI: 10.31086/tjgeri.2018137966

$2018 ; 21(1): 49-55$

- Meltem ALKAN MELIKOĞLU1

- Ayhan KUL 2

\section{Abstract}

Introduction: The aim of this study was to determine the fall risk in patients with knee osteoarthritis with an objective computerized technique and to evaluate the potential risk factors for falls in these patients.

Materials and Method: Patients with knee osteoarthritis and controls were included in this cross-sectional study. Gender, age, and body mass index were recorded. Pain was evaluated with a visual analog scale. The Western Ontario and McMaster Universities Osteoarthritis Index was used to assess the patients and the Falls Efficacy Scale International was used for the evaluation of fall efficacy. Knee radiographs were recorded with the Kellgren-Lawrence grading scale. Fall risk analysis was performed by using the Tetrax Interactive Balance System.

Results: One hundred patients with knee osteoarthritis and 30 controls were included. The age, gender, and body mass index scores were similar between the groups. Falls Efficacy Scale International scores were significantly higher in the cases than in the controls $(p<0.000)$. Using a computerized system, significantly higher fall risk results $(p<0.000)$ and significantly low, moderate, and high fall risk distribution were recorded in the cases than in the controls $(p<0.000)$. Fall risk was significantly related to age, pain, and the Western Ontario and McMaster Universities Osteoarthritis Index scores of the patients.

Conclusions: Our study demonstrated a higher fall risk in patients with knee osteoarthritis than in healthy individuals. This higher risk was shown even inå the early radiographic phases of the disease related to age, pain, and dysfunction. An understanding of factors on postural control seems to be critical in successful fall prevention in these patients.

Keywords: Osteoarthritis, Knee; Accidental falls; Postural balance

\section{CORRESPONDANCE}

\section{Dr. Ayhan KUL}

Erzurum Regional Training and Research Hospital, Department of Physical Medicine and Rehabilitation, Erzurum, Turkey

\section{Phone: 905335761514}

e-mail: drayhankul@gmail.com

\section{Received: 06/10/2017}

Accepted: 18/12/2017

1 taturk University, Faculty of Medicine, Department of Physical Medicine and Rehabilitation, Rheumatology,

\section{Erzurum, Turkey}

Erzurum Regional Training and Research Hospital, Department of Physical Medicine and Rehabilitation, Erzurum, Turkey

Presented In: Annual European Congress of Rheumatology : Madrid, Spain, 14-17 June 2017
ARASTTIRMA

\section{Diz OSTEOARTRITDE DÜŞME RISKi VE íLişKILi FAKTÖRLER}

\section{$\ddot{O}_{z}$}

Giriș: Bu çalışmanın amacı diz osteoartriti olan hastalardaki düşme riskini komputerize bir teknikle değerlendirmek ve bu hastalarda düşme riski için potansiyel risk faktörlerini belirlemektir.

Gereç ve Yöntem: Bu çalışmada, diz osteoartritli hastalar ve kontrol vakaları kesitsel olarak değerlendirildi. Katılımcıların cinsiyet, yaş ve beden kütle indeksi değerleri kaydedildi. Ağrı görsel analog skala ile, kısıtlılık"The Western Ontario and Mc Master Universities Osteoarthritis Index" ile, düşme etkisi ise "Falls Efficacy Scale International" ile değerlendirildi. KellgrenLawrence sınıflandırması kullanılarak diz radyografileri değerlendirildi. Düşme riski analizi ise "Tetrax Interactive Balance System" kullanılarak gerçekleştirildi.

Bulgular: Diz osteoartritli 100 hasta ve 30 kontrol vakası incelemeye alındı. Yaş, cinsiyet ve beden kütle indeksi değerleri gruplar arasında benzerdi. "Falls Efficacy Scale International" değerleri diz osteoartritli hastalarda kontrol grubundan anlamlı şekilde yüksekti $(p<0.000)$. Kullanılan komputerize sistemle, diz osteoartiti olan hastalarda kontrollere göre istatistiksel olarak anlamlı şekilde yüksek düşme riski $(p<0.000)$ ve düşük, orta ve yüksek düşme riski dağılımı kaydedildi $(p<0.000)$. Düşme riski hastaların "The Western Ontario and Mc Master Universities Osteoarthritis Index" skorları, yaş ve ağrıları ile belirgin derecede ilişkiliydi.

Sonuç: Çalışmamız, düşme riskinin diz osteoartritli hastalarda sağlıklı bireylerden daha yüksek olduğunu ortaya koymaktadır. Bu yüksek riskin yaş, ağrı ve disfonksiyon ile ilişkili şekilde hastalığın erken radyografik döneminde bile var olduğu gösterilmiştir. Postural kontrol üzerine etkili faktörlerin anlaşılması bu hastalarda düşmenin başarılı bir şekilde önlenmesinde önemli rol oynayacaktır.

Anahtar sözcükler: Diz osteoartriti; Düşme riski; Postural denge 


\section{INTRODUCTION}

Osteoarthritis (OA) is a chronic joint condition that affects one in ten adults (1). The knee is the joint most commonly affected in OA and knee OA (KOA) results in a loss of physical function (2). Balance, as a complex task, may be affected in KOA and this may cause postural instability and fall risk. A fall can be defined as "an unexpected event in which participants come to rest on the ground, floor or other lower level" according to the consensus guidelines (3). Its consequences are highly variable and may include loss of confidence, injury and even death (4). Although its etiology seems to be multifactorial which includes a complex interaction of intrinsic, behavioral or environmental risk factors, age and related comorbidities are considered to be the most important risk factors for falls in the normal population $(5,6)$. Rheumatic diseases were suggested as the second strongest independent risk factor for serious fall related injury in elderly (7). In spite of its reasonable commonness and often serious consequences in patients with rheumatic diseases, falls are still underestimated and poorly researched in this population. In studies about falls in patients with several rheumatic diseases, there is a wide range in reported falls incidence, which may be due to inconsistency in falls data attainment. Suggested potential fall risk factors were also conflicting as a result of the several different methodologies in previous studies. A definition of theterm "fall" is frequently missing from falls researches (8). The differences in falls rates in previous studies have been attributed to variation in the definition of a fall event (4). Also most of the previous studies used "self-reported" falls data. An objective technique seems to be needed in the evaluation of fall risk in these patients.

In our research, we couldn't find any study investigating fall risk in patients with KOA with an objective technique. To determine the fall risk and related risk factors in these patients may lead to the awareness and prevention of falls and may contribute to the management. The aim of this study was to determine the fall risk in patients with $\mathrm{KOA}$ with an objective computerized technique and to evaluate the potential related risk factors for falls in these patients.

\section{MATERIALS AND METHOD}

\section{Patients}

This cross-sectional study was approved by the Local Ethics Committee and it was conducted in accordance with the 1989 Declaration of Helsinki. All subjects signed an informed consent form before participating in the study. After calculating the sample size as 28 with $95 \%$ reliability and $\pm 5 \%$ deviation, one hundred patients (for 4 subgroups) with $\mathrm{KOA}$ and 30 healthy controls with similar age (range 40-75 years) and gender profile were included in the study. All patients fulfilled the combined clinical and radiographic criteria of knee OA, as established by the American College of Rheumatology $(9,10)$. Patients who were not able to cooperate or tolerate the fall risk evaluation, patients with a history of or previous orthopedic surgery, with a known balance problem or patients using medicines that may cause balance disorder were excluded from the study. The control subjects were selected among hospital stuff and their relatives in order to make a similar age profile to patients.

\section{Evaluations}

The characteristics of the participants including gender, ages and body mass index (BMI) were recorded. Pain vas evaluated with visual analogue scale (VAS).

Western Ontario and McMaster Universities Osteoarthritis Index (WOMAC) was used to assess the patients with KOA (11). It has been used to assess pain, stiffness, and physical function in patients with OA. The WOMAC consists of 24 items divided into 3 subscales: Pain (5 items), stiffness (2 items) and physical function (17 items). On the Likert scale version, the scores are summed for items in each subscale, with possible ranges as follows: pain $=0-20$, stiffness $=0-8$, physical function $=0-68$.

The grading of knee radiographs was performed by an experienced observer who was blinded to the 
source of subjects. Knee radiographs were scored with the Kellgren-Lawrence grading scale (Grade I-IV) (12).

For the evaluation of fall efficacy in patients with KOA, we used the Falls Efficacy Scale International (FES-I) which is a self-reported questionnaire. This scale is a short, easy to administer tool that measures the level of concern about falling during social and physical activities inside and outside the home whether or not the person actually does the activity. It contains 16 items scored on a four point Likert scale $(1=$ not at all concerned to $4=$ very concerned) providing a total score ranging from 16 (absence of concern) to 64 (extreme concern). The FES-I was developed in a collaborative effort with members of the Prevention of Falls Network Europe (ProFaNE) (13) and it was translated into several languages as well as our language (14). Fall risk analysis of patients with KOA and controls were performed by Tetrax Interactive Balance System (Sunlight Medical Ltd., Israel) with the same technique which is directed by the user's guide of the device. Tetrax static posturography device has a computer and software system, and all the data obtained from the device were the results of the software. The device uses a system of force gauges in four plates on which subject stands, and translates the vertical forces on the plates into wave signals into a computer digitally. Before the task, the patients were instructed to place their feet side by side on lined places of the platform in shape of feet, not to speak and move during the task. Measurements are made in eight different positions in all subjects with the same technique, sequence, and directions (each position takes about $40 \mathrm{~s}$ ): (i) head straight, eyes open, on a hard ground; (ii) head straight, eyes closed, on a hard ground; (iii) head straight, eyes open, on a soft ground (sponge under feet); (iv) head straight, eyes closed, on a soft ground; (v) head turned to the right, eyes closed, on a hard ground; (vi) head turned to the left, eyes closed, on a hard ground; (vii) neck fully extended, eyes closed, on a hard ground; and (viii) neck fully flexed, eyes closed, on a hard ground (15). A fall index derived from Tetrax balance parameters has been developed to produce a score that will express the patient's risk of falling based on the specific balance factors that affect falling. Fall risk is a numeric value from 0 to 100, with three numerical ranges 0 to 35 , 36 to 57 , and 58 to 100 , indicating low, moderate, or high risk of fall, respectively (16).

\section{Statistical analysis}

Analyses were performed using the SPSS 20.0 software package program. Descriptive data were presented as mean \pm standard deviation (sd). Mann-Whitney U, one-way ANOVA and Spearman correlation tests were used for statistical analysis. $\mathrm{P}$ values less than 0.05 were considered statistically significant.

\section{RESULTS}

Eleven patients were excluded from the study for the following reasons: patients Three patients due to the non-cooperation in computerized measurements, one patient due to previous orthopedic surgery and seven patients using medicines that may cause balance disorder. Finally, one hundred patients with KOA (55 female and 45 male) and age and gender similar 30 controls (17 female and 13 male) were included in our study. The mean ages of the patients and controls were $64.7 \pm 10,6$ and 62.811 .4 years, respectively. The BMI scores were similar between patients and controls. FES-I scores were found to be significantly higher in cases than controls $(36 \pm 4$ and $20 \pm 2$ respectively; $p<0.000$ ). With the computerized system used, significantly higher fall risk results were recorded in patients than the controls $(68,2 \pm 28,1$ and $35,8 \pm 26,9$, respectively; $\mathrm{p}<0.000)$. Low, moderate and high fall risks were recorded as $14 \%, 24 \%$ and $62 \%$ of the cases and $53 \%, 23 \%$ and $23 \%$ of the controls. This distribution was also significantly worse in cases than controls $(p<0.000)$. The comparisons of the demographic characteristics, BMI, scores of FES-I and fall risk assessments of the participants were shown in Table 1.

We compared the scores of FES-I and fall risk assessments among KOA radiographic grade 
subgroups (grade 0-IV). As possible related factors to fall risk, age and BMI scores were not significantly different among groups, although grade IV group had a slight higher age profile (data were not shown). FES-I was significantly higher in grade III and IV compared to controls ( $p<0.05$ and 0.001 respectively). Fall risk assessment was significantly higher in patient groups than controls as well $(p<0.05$ for grade I compared to controls and $p<0.001$ for other grades compared to controls). This was also similar for fall risk category. Among $\mathrm{OA}$ subgroups (radiological grade I-IV), in spite of increasing scores infall risk and fall risk categories, the differences were not able to reach to statistical significance in the post hoc analysis. Data were shown in Table 2.

We evaluated the correlation between fall risk assessment and patients' characteristics including gender, age, BMI, radiographic grade, pain and WOMAC. It was demonstrated that fall risk was significantly correlated with age, pain and WOMAC scores of the patients. Data were shown in Table 3.

Table 1. Demographic characteristics, BMI, scores of FES-I and fall risk assessments of the participants.

\begin{tabular}{|c|c|c|c|}
\hline Variable & $\begin{array}{r}\text { Patientswith KOA } \\
(n=100) \\
\end{array}$ & $\begin{array}{r}\text { Controls } \\
(n=30)\end{array}$ & $p$ \\
\hline Age (years) & $64.7(s d=10.6)$ & $62.8(\mathrm{sd}=11.4)$ & NS \\
\hline $\begin{array}{l}\text { Gender } \\
\text { Female/ Male (n) }\end{array}$ & $55 / 45$ & $17 / 13$ & NS \\
\hline $\mathrm{BMI}\left(\mathrm{Kg} / \mathrm{m}^{2}\right)$ & $33.5(\mathrm{sd}=5.7)$ & $32.1(\mathrm{sd}=6.8)$ & NS \\
\hline FES-I (16-64) & $36(s d=4)$ & $20(s d=2)$ & 0.000 \\
\hline Fall risk assessment (0-100) & $68.2(\mathrm{sd}=28.1)$ & $35.8(\mathrm{sd}=26.9)$ & 0.000 \\
\hline $\begin{array}{l}\text { Fall risk category } \\
\text { Low (0 to } 35) n(\%) \\
\text { Moderate }(36 \text { to } 57) n(\%) \\
\text { High (58 to 100) n (\%) }\end{array}$ & $\begin{array}{l}14(14) \\
24(24) \\
62(62)\end{array}$ & $\begin{array}{r}16(53) \\
7(23) \\
7(23)\end{array}$ & 0.000 \\
\hline
\end{tabular}

KOA; knee osteoarthritis, NS; not significant, FES-I; Falls Efficacy Scale International

Table 2. Comparison of the scores of FES-I and fall risk assessments among KOA radiographically graded subgroups.

\begin{tabular}{|c|c|c|c|c|c|}
\hline & $\begin{array}{r}\text { Grade } 0 \\
\text { (controls) } \\
(n=30)\end{array}$ & $\begin{array}{r}\text { Grade I } \\
(n=21)\end{array}$ & $\begin{array}{r}\text { Grade II } \\
(n=27)\end{array}$ & $\begin{array}{r}\text { Grade III } \\
(n=28)\end{array}$ & $\begin{array}{r}\text { Grade IV } \\
(n=24)\end{array}$ \\
\hline FES-I (16-64) & $20.6(s d=16.2)$ & $24.1(\mathrm{sd}=7.5)$ & $31.8(\mathrm{sd}=21.4)$ & $34.9(\mathrm{sd}=16.9)^{\star}$ & $\begin{array}{r}61.7 \\
(s d=22.1)^{\star *}\end{array}$ \\
\hline $\begin{array}{l}\text { Fall risk assessment } \\
(0-100)\end{array}$ & $35.8(\mathrm{sd}=26.9)$ & $\begin{array}{r}60.2 \\
(s d=36.4)^{\star}\end{array}$ & $70.6(s d=27.3)^{\star \star}$ & $\begin{array}{r}66.5 \\
(s d=27.2)^{\star \star}\end{array}$ & $\begin{array}{r}72.0 \\
(s d=24.8)^{\star \star}\end{array}$ \\
\hline $\begin{array}{l}\text { Fall risk category } \\
\text { Low (0 to } 35)(\%) \\
\text { Moderate (36 to } 57)(\%) \\
\text { High (58 to } 100)(\%)\end{array}$ & $\begin{array}{l}53 \\
23 \\
23\end{array}$ & $\begin{array}{r}40^{*} \\
6 \\
53^{*}\end{array}$ & $\begin{array}{r}12^{\star \star} \\
21 \\
66^{\star \star}\end{array}$ & $\begin{array}{r}7 * \star \\
35 \\
57^{\star \star}\end{array}$ & $\begin{array}{r}8^{* *} \\
25 \\
66^{* *}\end{array}$ \\
\hline
\end{tabular}

FES-I: Falls Efficacy Scale International

${ }^{*} \mathrm{p}<0.05$; compared to controls

${ }^{\star \star} \mathrm{p}<0.000$; compared to controls 
Table 3. The correlations between fall risk assessment and patients' characteristics.

\begin{tabular}{lcr}
\hline Variable & Fall risk assessment & Fall risk category \\
\hline Gender & $\mathrm{NS}$ & $\mathrm{NS}$ \\
& 0.367 & 0.368 \\
Age & 0.000 & 0.000 \\
& $\mathrm{NS}$ & $\mathrm{NS}$ \\
BMI $\left(\mathrm{kg} / \mathrm{m}^{2}\right)$ & $\mathrm{NS}$ & $\mathrm{NS}$ \\
Radiologicalgrade & & $0.388 \mathrm{r}$ \\
WOMAC & $0.345 \mathrm{r}$ & $0.001 \mathrm{p}$ \\
Pain & $0.001 \mathrm{p}$ & $0.374 \mathrm{r}$ \\
Stiffness & $0.381 \mathrm{r}$ & $0.001 \mathrm{p}$ \\
& $0.001 \mathrm{p}$ & $0.359 \mathrm{r}$ \\
Physicalfunction & $0.376 \mathrm{r}$ & $0.001 \mathrm{p}$ \\
& $0.001 \mathrm{p}$ & $\mathrm{NS}$ \\
Pain (VAS; 0-10) & $0.176 \mathrm{r}$ & $0.05 \mathrm{p}$ \\
\hline
\end{tabular}

BMI: Body Mass Index

WOMAC: The Western Ontario and McMaster Universities Osteoarthritis Index

\section{DISCUSSION}

With an objective computerized technique, fall risk found to be higher in patients with KOA than controls in this study. This higher risk was correlated with age, WOMAC sores and pain, but not with OA radiological grade.

Our results showing higher fall risk in patients with $\mathrm{KOA}$ with an objective technique is compatible with several previous studies highlighting the high incidence of falls in these patients (17-19). OA has been reported to be associated with an increased risk of falling, with fall rates up to $50 \%$ of individuals with $\mathrm{OA}$, compared to $30 \%$ of healthy older adults (1). Our results; with its methodology using an objective computerized technique, may contribute to previous studies mostly used "self-reported" falls data.

In our study the higher fall risk in KOA was found to be age related regardless of the gender of the patients. Although a few studies has described possible gender differences in falls, previous studies seem to be in a consensus on the effect of the increasing age on fall risk in patients with KOA
$(1,20-22)$. In fact, OA prevalence increases with age, with $30 \%$ of those over the age of 75 exhibiting severe radiographic disease (2). Aging is associated with significant changes in dynamic postural control which is a central factor in fall risk. Higher fall risk in KOA related to increasing age may be the consequence of normal aging associated with neuromuscular changes. However, those with KOA have been reported to be at a higher risk of falls than healthy elderly individuals $(18,21)$. Similarly, in our study, fall risk was found to be higher in patients with KOA than age similar controls. In order to develop fall prevention strategies for patients with $\mathrm{KOA}$, it is important to understand the role other deficits beyond normal aging that are attributed to the disease.

In this study pain was found to be related to increased fall risk in patients with KOA. Similarly, the relation between pain and falls were demonstrated in previous studies with different methodologies $(23,24)$.

Joint pain is a central characteristic of $O A$ and it alters the kinematics and kinetics of postural 
responses (1). Due to the link between pain and the increased risk of falls, whether pain relief will be effective in reducing the risk of falls in these patients needs to be researched.

Impaired physical function was one of the related factors to fall risk in our study. Similarly reduced functions were found as an associated factor to increased risk of falling in previous studies (24). Also in a previous study using the same scale with us, KOA patients with a fall history had a worse functional status as measured by WOMAC when compared to those without such an anamnesis (25). Our objective results were parallel to previous studies demonstrating correlation between fall risk and functional status.

In our study, when compared one by one each subgroup of patients (Grade I-IV radiologically) to controls, all groups showed higher fall risk scores than healthy individuals. However, in spite of

\section{REFERENCES}

1. Takacs J, Carpenter MG, Garland SJ, Hunt MA. The role of neuromuscular changes in aging and knee osteoarthritis on dynamic postural control. Aging Dis 2013 Jan;4(2):84-99. (PMID:23696951).

2. Bakilan F, Armagan O, Ozgen M, Tascioglu F, Bolluk $O$, Alatas $O$. Effects of native type ii collagen treatment on knee osteoarthritis: a randomized controlled trial. Eurasian J Med 2016;48(2):95-101. (PMID:4970562).

3. Lamb SE, Jorstad-Stein EC, Hauer K, Becker C. Development of a common outcome data set for fall injury prevention trials: The Prevention of Falls Network Europe consensus. J Am Geriatr Soc 2005;53:1618-22. (PMID:16137297).

4. Brenton-Rule A, Dalbeth N, Bassett S, Menz HB, Rome K. The incidence and risk factors for falls in adults with rheumatoid arthritis: a systematic review. Semin Arthritis Rheum 2015;44:389-98. (PMID:25216947).

5. McKay C, Anderson KE. How to manage falls in community dwelling older adults: a review of the evidence. Postgrad Med J 2010;86:299-306. (PMID:20406801). increasing fall risk scores among radiological graded subgroups of patients with KOA, the differences were not able to reach to statistical significance. Our study demonstrated a higher fall risk even in radiologically grade I KOA than controls. It may be considered that higher fall risk may be present in the early phases of KOA. Patients with KOA exhibit several neuromuscular changes beyond that seen with aging. Future researches are needed to evaluate the effect of such changes on postural control.

In conclusion, with an objective technique, our study demonstrated a higher fall risk in patients with KOA than healthy controls. This higher risk was shown even in the early radiographic phases of the disease related to age, pain and dysfunction. In addition to the known effects of aging in balance, an understanding of other neuromuscular factors on postural control seems to be critical in successful fall prevention in patients with $\mathrm{KOA}$.

6. Deandrea S, Lucenteforte E, Bravi F, Foschi R, LaVecchia C, Negri E. Risk factors for falls in community-dwelling older people: a systematic review and meta-analysis. Epidemiology 2010;21:658-68. (PMID:20585256).

7. Bergland A, Wyller TB. Risk factors for serious fall related injury in elderly women living at home. Inj Prev 2004;10:308-13.(PMID:15470013).

8. Hauer K, Lamb SE, Jorstad EC, Todd C, Becker C. Systematic review of definitions and methods of measuring falls in randomized controlled fall prevention trials. Age Ageing 2006;35:5-10. (PMID:16364930).

9. American College of Sports Medicine Position Stand (ACSM). Progression models in resistance training for healthy adults. Med Sci Sports Exerc.2009;41:687-708. (PMID:19204579).

10. Fernandes L, Hagen KB, Bijlsma JQJ, et al. EULAR recommendations for the non-pharmacological core management of hip and knee osteoarthritis. Ann Rheum Dis 2013;72:1125-35. (PMID:23595142). 
11. Bellamy N, Buchanan W, Goldsmith C, Campbell J, Stitt L. Validation study of WOMAC health status instrument for measuring clinically important patient relevant outcomes to antirheumatic drug therapy in patients with osteoarthritis of the hip or knee. J Rheumatol 1988;15:1833-40. (PMID:3068365).

12. Kellgren JH, Lawrence JS. Radiologic assessment of osteoarthritis. Ann Rheum Dis 1957 Dec;16(4):494502. (PMID:13498604).

13. Yardley L, Beyer N, Hauer K, Kempen G, Piot-Ziegler C, Todd C. Development and initial validation of the Falls Efficacy Scale- International (FES-I). Age and Ageing 2005;34:614-9. (PMID:16267188).

14. Ulus Y, Durmus D, Akyol Y, Terzi Y, Bilgici A, Kuru $O$. Reliability and validity of the Turkish version of the Turkish version of the Falls Efficacy Scale International (FES-I) in community-dwelling older persons. Arch Gerontol Geriatr 2012;54:429-33. (PMID:21831462).

15. Akkaya N, Akkaya S, Atalay NS, Acar M, Catalbas $N$, Sahin F. Assessment of the relationship between postural stability and sleep quality in patients with fibromyalgia. Clin Rheumatol 2013;32:325-31. (PMID:23179001).

16. Ozdemir O, GokceKutsal Y. Fall risk assessment of elderly by using posturography. Turk J Geriatr 2009; 12:177-80.

17. Prieto-Alhambra D, Nogues $X$, Javaid MK, et al. An increased rate of falling leads to a rise in fracture risk in post menopausal women with self-reported osteoarthritis: a prospective multinational cohort study (GLOW).Ann Rheum Dis 2013;72:911-7. (PMID:22730372).

18. Scott D, Blizzard L, Fell J, Jones G. Prospective study of self-reported pain, radiographic osteoarthritis, sarcopenia progression, and falls risk in communitydwelling older adults. Arthritis Care Res (Hoboken) 2012;64:30-7. (PMID:21739619).
19. Wright NC, Lisse JR, Walitt BT, Eaton CB, Chen Z. Arthritis Increases the Risk for Fractures-Results from the Women's Health Initiative. J Rheumatol 2011;38: 1680-8. (PMID:21572148).

20. Prieto-Alhambra D, Judge A, Javaid MK, Cooper C, Diez-Perez A, Arden NK. Incidence and risk factors for clinically diagnosed knee, hip and hand osteoarthritis: influences of age, gender and osteoarthritis affecting other joints. Ann Rheum Dis 2014;73:1659-64. (PMID:23744977).

21. Levinger $P$, Menz HB, Wee E, Feller JA, Bartlett JR, Bergman NR. Physiological risk factors for falls in people with knee osteoarthritis before and early after knee replacement surgery. Knee Surg Sports Traumatol Arthrosc 2011;19:1082-9. (PMID:21107530).

22. Williams SB, Brand CA, Hill KD, Hunt SB, Moran H. Feasibility and outcomes of a home-based exercise program on improving balance and gait stability in women with lower-limb osteoarthritis or rheumatoid arthritis: A pilot study. Arch Phys Med Rehabil 2010;91:106-14. (PMID:20103404).

23. Muraki S, Akune T, Oka H, En-Yo Y, Yoshida M, Nakamura K, Kawaguchi H, Yoshimura N. Prevalence of falls and the association with knee osteoarthritis and lumbar spondylosis as well as knee and lower back pain in Japanese men and women. Arthritis Care Res (Hoboken) 2011;63:1425-31. (PMID:21793231).

24. Levinger P, Wallman S, Hill K. Balance dysfunction and falls in people with lower limb arthritis: factors contributing to risk and effectiveness of exercise interventions. Eur Rev Aging Phys Act 2012; 9:17-25.

25. Bugdayci DS, Paker N, Tekdos D, Topal K, Erbil E, Ersoy S. The functional status of knee in faller or non-faller female patients with knee osteoarthritis. Turkish J Physical Med Rehab 2012;58:22-5. 